\title{
Alginate biopolymer production by Azotobacter chroococcum from whey degradation
}

\author{
*A. Khanafari; A. Akhavan Sepahei
}

Department of Microbiology, Islamic Azad University, North Tehran Branch, Tehran, Iran

Received 18 Janurary 2007; revised 20 March 2007; accepted 25 July 2007; available online 1 September 2007

\begin{abstract}
The potential of three Azotobacter chroococcum strains for whey degradation and alginate production were investigated. After dilution, samples were spread plated on isolation agar and Manitol agar and incubated at $30{ }^{\circ} \mathrm{C}$ for $24 \mathrm{~h}$. Microorganisms were screened for their ability to whey degradation and alginate production based on colony morphology, negative and capsule staining, ability to decrease the apparent turbidity of the fermentation broths in batch and semi continuous culture by spectrophotometer assay at 400 nanometer and tensiometer assay. Of the three strains tested for whey degradation, only Azotobacter chroococcum 1723 produced significant apparent growth on whey broth and could decrease about $70 \%$ of turbidity in fermentation broth during 6 days in batch culture. Colonies of this strain was characteristically yellow, large, moucoid and slimy on whey agar than Manitol agar after $24 \mathrm{~h}$ at $30{ }^{\circ} \mathrm{C}$. Transmission electron microscopy assay and Carbazole reagent were used to recognize the alginate biopolymer. After optimizing environmental factors such as $\mathrm{pH}$, salt concentration and temperature, this strain was able to produce exopolysaccharide greater than $5 \mathrm{mg} / \mathrm{mL}$. Optimum results were obtained when using whey broth as a fermentation medium without extra salt, temperature at $35{ }^{\circ} \mathrm{C}$ and $\mathrm{pH}$ 7. Increasing inorganic and organic nitrogen sources (yeast extract and $\mathrm{NH}_{4} \mathrm{NO}_{3}$ ) reduced whey degradation at least $30 \%$. Transmission electron microscopy assay showed a net-structured polysaccharide capsule around the cells. Semi-continuous culture results demonstrated that, alginate production as well as whey degradation was decreased (1 mg/mL and $30 \%)$.
\end{abstract}

Key words: Azotobacter chroococcum, whey degradation, alginate production and exopolysaccharide

\section{INTRODUCTION}

Extracellular polysaccharide (EPS) is required for wildtype virulence of Pseudomonas solanaceaum and other microorganisms (Willis, et al., 2001). Many of them produced by microorganisms have been studied and are currently used in a wide range of industries due to their functions such as gel formation, emulsifying film formation, and antitumor activity (Low, et al., 1998). Alginates are linear copolymers of $\beta$-D-mannuronic acid (M) and it's C-5-epimer, $\alpha$-L-guluronic acid (G) and it is a commercially important polysaccharide which has many applications in biotechnology and food industry (Grasdalen, et al., 1983). Alginate immobilized cell systems are used as biocatalysts in several industrial processes such as ethanol production by yeast cell, production of monoclonal antibodies from hybridoma cells (Crescenzi, 1995), stimulating immune cells to secrete cytokines, such as Tumor Necrosis Factor- $\alpha$ (TNF- $\alpha$ ), Interleukin-1 (IL-1) and Interleukin-6 (IL-6) (Otterlei, et al., 1991), used in water treatment processes

$\triangle$ *Corresponding Author Email: khanafari_a@yahoo.com Tel.: +9821 2208 2141; Fax: +9821 22700103 since they help in increasing the aggregate sizes in the flocculation processes (Dekwer and Hempel, 1999), used mainly in food industry, for example, in ice-creams, frozen custards, as well as cream, cake mixtures and in beer manufacture to enhance the foam and fruit drinks to assist the suspension of fruit pulp, which makes the product more appealing to the consumer (Neidleman, 1991). All alginates used for commercial purposes are currently being produced the harvesting of brown seaweeds. However, considering the quality of bacterial alginate and the environmental impact associated with seaweed harvesting and processing, it is more probable that bacterial alginate may become commercial product (Dekwer and Hempel, 1999). Several bacteria specially Pseudomonas spp. and Azotobacter spp. can synthesize alginate. The species Azotobacter vinelandii seems to be the best candidate for the industrial production of alginate molecules characterized by a chemical composition, molecular mass and molecular mass distribution suited to a well defined application, especially required in the biotechnological, biomedical 
and pharmaceutical fields (Clementi, 1997). All alginates produced by bacteria were, in all cases, reported to be rich in mannuronic acid (Dekwer and Hempel, 1999). Azotobacter spp is a gram negative soil bacterium which under adverse environmental conditions undergoes a differentiation process leading to the formation of desiccation- resistant cysts (Dekwer and Hempel, 1999). The mature cysts are surrounded by two capsule-like layers containing a high proportion of the exopolysaccharide alginate. This exopolysaccharide is essential for the encystment process, since nonmucoid strains fail to encyst (Campos, et al., 1996). In Azotobacter vinelandii, alginate protects nitrogenase from oxygen and increases nitrogen fixation (Sabra, et al., 2000). In the case of the dairy industry, one such 'waste' which is produced in enormous quantities is the whey resulting from cheese and casein manufacture. Whey is the serum part of milk remaining after separation of the curds during casein or cheese making (Zadow, 1986). It is rich in nutrients and contains at least half the solids found in whole milk (Horton, 1993). The other perspective, whey has a very strong polluting capacity, with a biological oxygen demand (BOD) of 40,000 to 45,000 mg/L (Hacking, 1988; Kemp and Quickenden, 1989). On a world wide scale, only $50 \%$ (v/v) of total whey produced is utilized, and the remainder is disposed of disposed whey is either discharged into the sewage or ocean outfall or is sprayed on pastures (Zadow, 1987;1992). In recent years, value added products form whey have attracted much interest. One such area is the production of microbial biopolymer (Schwartz and Bodie, 1985; Fu and Tseng, 1990; Flatt, et al., 1992; Konicek, et al., 1993). In this study, the potential of native Azotobacter chroococcum strains for degradation whey when grown on whey medium to produce exopolymer like alginate were investigated.

\section{MATERIALS AND METHODS}

This research was carried out in Department of Microbiology in the Microbiology Laboratory, Islamic Azad University, North Tehran Branch, Iran during 2006 to 2007. All data reported in this study are from triplicate measurement.

Bacterial strains, culture conditions, and estimation of bacterial concentration

Three strains of Azotobacter chroococcum were studied for alginate production (Table 1). The strains were originally obtained from Microbiology Laboratory, Faculty of Science, Islamic Azad University, North
Tehran Branch, Iran. Samples subcultured on Manitol agar (Oxoid) and Whey agar [0.1\% (w/v) yeast extract, $0.1 \%(\mathrm{w} / \mathrm{v})$ yeast extract (Oxoid), $0.05 \%(\mathrm{w} / \mathrm{v}) \mathrm{K}_{2} \mathrm{HPO}_{4}$, $0.01 \%$ (w/v) $\mathrm{NH}_{4} \mathrm{NO}_{3}, 100 \%$ (w/v) whey broth, $1.5 \%$ Bacto agar (Merk), pH was adjusted to 7 using $5 \mathrm{M}$ $\mathrm{NaOH}]$ and incubated at $30{ }^{\circ} \mathrm{C}$ for 24-48 h. After dilution, samples were spread plated on Isolation agar (IA), [2 \% (w/v) lactose (Oxoid), $0.5 \%$ (w/v) peptone (BBL), $0.25 \%(\mathrm{w} / \mathrm{v})$ yeast extract (Oxoid), $1.5 \%$ Bacto agar (Merk), pH was adjusted to 7 using $5 \mathrm{M} \mathrm{NaOH}$ ] and incubated at $30^{\circ} \mathrm{C}$ for $24 \mathrm{~h}$ to screening biopolymer producer bacteria. The broth used for screening of whey utilizing commercial biopolymer producer contained: $0.1 \%(\mathrm{w} / \mathrm{v})$ yeast extract, $0.05 \%(\mathrm{w} / \mathrm{v})$ malt extract (Oxoid), $0.05 \%$ (w/v) $\mathrm{K}_{2} \mathrm{HPO}_{4}, 0.01 \%$ (w/v) $\mathrm{NH}_{4} \mathrm{Cl}, 0.01$ $\%(\mathrm{w} / \mathrm{v}) \mathrm{MgSO}_{4}$. This medium was prepared with different $\mathrm{pH}$ (4-9), added inorganic and organic nitrogen sources (yeast extract and $\mathrm{NH}_{4} \mathrm{NO}_{3}, 1 \%$ ), and kept at different temperature $\left(25,30,35,37^{\circ} \mathrm{C}\right)$ to optimize alginate production. Gram and capsules stains were used for staining bacteria.

\section{Proximate analysis of whey}

The whey used in this study was characterized for its composition. The lactose, proteins and fats were determined using the Milko Scan method (Microbalance 4503 MP6). Mineral composition, Ca, K and Na were determined by atomic absorption (Varian Spectra AA. 200). The nitrogen was determined using the Kjeldahl method (Kirk and Sawyer, 1991).

\section{Exopolysaccharide production}

To test the ability of bacterial cultures to produce biopolymers in whey, colonies that were mucoid, ropy and capsule positive were cultured in whey broth as fermentation broth. This medium was prepared in 250 $\mathrm{mL}$ conical flasks containing $50 \mathrm{~mL}$ of broth. Shake flask incubations were done at $30{ }^{\circ} \mathrm{C}$ and $120 \mathrm{rpm}$. Samples were taken every $24 \mathrm{~h}$ to measure optical density $\left(\mathrm{OD}_{400}\right)$ by spectrophotometer assay (CARY 50 scan UV/Vis spectrum spectrophotometer). The ability of bacteria to produce exopolysaccharide was determined by increase of broth apparent viscosity or presence of gel or pellicle in fermentation broth (Schwartz and Bodie, 1985).

Table 1: Source of bacterial strains used in the study

\begin{tabular}{llc}
\hline Identification & Strain & Source \\
\hline Azotobacter chroococcum & DSM No. 281 & Soil \\
Azotobacter chroococcum & DSM No. 398 & Soil \\
Azotobacter chroococcum & DSM No. 1723 & Soil \\
\hline
\end{tabular}




\section{Biopolymer recovery and purification}

Recovery and purification of microbial exopolysaccharide were adapted with some slight modifications according to Vendrusculo, et al., (1994). The fermentation broths were diluted 5 to 10 fold with redistilled water to reduce the viscosity. Cells were removed by centrifugation by Sorval Model RC5B at $39000 \mathrm{~g}$ for $30 \mathrm{~min}$ and supernatant was recovered by decanting. Freeze dried samples were ground into fine powder and stored in a desicator. The dilute supernatant was concentrated to its initial volume by ultra-filtration, using the YM30 membranes. The concentrates were treated with $5 \mathrm{M}$ Trichloro acetic acid $(30 \mathrm{~mL} / 100 \mathrm{~mL}$ sample) to remove the proteins, and then neutralized with $5 \mathrm{M} \mathrm{NaOH}$. The protein precipitates were further concentrated by ultra-filtration. The retentate was washed two times to remove lactose or other low molecular mass carbohydrates. In permeate and lactose rich broths, acid treatment were omitted. There volumes of chilled absolute ethanol were added to precipitate the polysaccharide. To enhance precipitation, these samples were stored at $40^{\circ} \mathrm{C}$ for $24 \mathrm{~h}$. The precipitates were recovered by centrifugation at $12,000 \mathrm{~g}$ at $40{ }^{\circ} \mathrm{C}$ for $30 \mathrm{~min}$ and dissolved in distilled water. This solution was subjected to ultra-filtration and washed twice redistilled water. The retained material was dissolved in distilled water for $24 \mathrm{~h}$. This solution was precipitated as described above and lyophilized by Snijders scientific 2040 VDH lyophilizer.

\section{Drying of polysaccharide samples}

The alcohol precipitated samples were transferred to sample jars and frozen at $20^{\circ} \mathrm{C}$ for $24 \mathrm{~h}$. The frozen samples were freeze dried at $-500 \mathrm{c}$ and $100 \mathrm{kPa}$ vacuum. Freeze drying was done until constant weights were achieved (30 to $48 \mathrm{~h})$.

\section{Surface tension measurement}

Surface tension was measured using a Du Nouy tensiometer. Measurements were made on supernatant samples after centrifugation.

\section{Alginate Recognition assays \\ Transmission electron microscopy assay}

Transmission electron microscopy was used to investigate the alginate concentration gradient around the cells was adapted with some slight modifications according to Dekwer and Hempel, (1999). Samples were picked up with carbon-coated collodion grids. The grids were plotted with filter paper, and alginate was positively contrasted by incubation on freshly prepared $1 \%$ aqueous ruthenium red solution for $1-2 \mathrm{~min}$ at room temperature. The grids were washed three times with distilled water by paper blotting. Finally the cells were negatively stained with $1 \%$ uranyl acetate for $10 \mathrm{~s}$, blotted, and air dried. Electron microscopy was done with LEOi at $80 \mathrm{kV}$ with a magnification between 16,000 and 25,000.

Reaction of alginate sample with and without borate (by use Carbazole reagent)

Reaction of alginate sample with Carbazole reagent was adapted with some slight modifications according to Dekwer and Hempel, (1999). After Carbazole reagent was added to sample, mixed and heated at $55^{\circ} \mathrm{C}$ for 30 min, color was stable for $2 \mathrm{~h}$ at room temperature. Standard curves of mannuronic acid as well as guluronic acid were made for the two reaction conditions (with and without borate).

\section{Semi continuous culture of Azotobacter spp to whey degradation}

A semi continuous culture was performed using Azotobacter chroococcum growing in whey broth medium to test the ability of whey degradation. The culture was then aerated and agitation speed was set at $200 \mathrm{rpm}$. Samples incubated at $30^{\circ} \mathrm{C}$ for $24 \mathrm{~h}$ and optical density was measured after every replacement times at $400 \mathrm{~nm}$ (CARY 50 scan UV/Vis spectrum spectrophotometer).

\section{Statistical analysis}

Significant differences between bacterial treatments were tested by analysis of variance using Minitab. Data were normalized, and Tukey tests were performed. The results of different incubated time experiments were subjected to Student's $t$ test to identify significant differences between bacterial treatments. Probability $(P)$ values of $<0.05$ were considered significant.

\section{RESULTS}

All strains were studied exhibited significant growth in whey agar than Manitol agar media. The results also show that two strains of Azotobacter chroococum (1723 and 398 ) in whey agar media, were produced colonies that were mucoid, ropy and capsule positive with yellow pigment in $24 \mathrm{~h}$ at $30^{\circ} \mathrm{C}$. There was insignificant growth observed up to $48 \mathrm{~h}$ in Manitol agar. 
These strains were regarded as efficient producer and were subjected to further study. They were able to use whey as fermentation substrate for biopolymer production. After optimizing environmental factors such as $\mathrm{pH}$, salt concentration and temperature, Azotobacter chroococum 1723 was able to produce exopolysaccharide greater than $5 \mathrm{mg} / \mathrm{mL}$. This corresponded to broths' apparent viscosities of at least $25 \mathrm{cP}$ at 0.6/s. In Azotobacter chroococum 1723, biopolymer production was minimum yield in Manitol broth, while maximum production was obtained from whey broth. Composition of the whey broth medium used in this study presented on Table 2 . Optimum results were obtained when using whey broth as a fermentation medium without extra salt, temperature at $35^{\circ} \mathrm{C}$ and $\mathrm{pH}$ $7(P<0.05)$. This strain was able to produce biopolymer under uncontrolled $\mathrm{pH}$ condition. Maximum results were obtained in fermentations where the $\mathrm{pH}$ was maintained at 7 . When fermentations were done in whey broth under aerated conditions, there was no improvement in polymer production and whey degradation. Increasing yeast extract and $\mathrm{NH}_{4} \mathrm{NO}_{3}$ as organic and inorganic nitrogen

Table 2: Composition of the whey broth medium

\begin{tabular}{lll}
\hline Whey Constituents & Amount (\% w/v) & SD \\
\hline Lactose & 4.91 & 0.3 \\
Proteins & 0.93 & 0.05 \\
$\mathrm{~N}_{2}$ & 0.13 & 0.04 \\
Fats & 0.71 & 0.01 \\
$\mathrm{Ca}$ & $4.95 \mathrm{ppm}$ & 0.1 \\
$\mathrm{~K}$ & $0.93 \mathrm{ppm}$ & 0.04 \\
$\mathrm{Na}$ & $0.078 \mathrm{ppm}$ & 0.07 \\
Total solids & 6.25 & 0.05 \\
\hline
\end{tabular}

Each value is a mean \pm (standard deviation=SD) of triplicate assays. *Indicates a significant $(P<0.05)$ difference

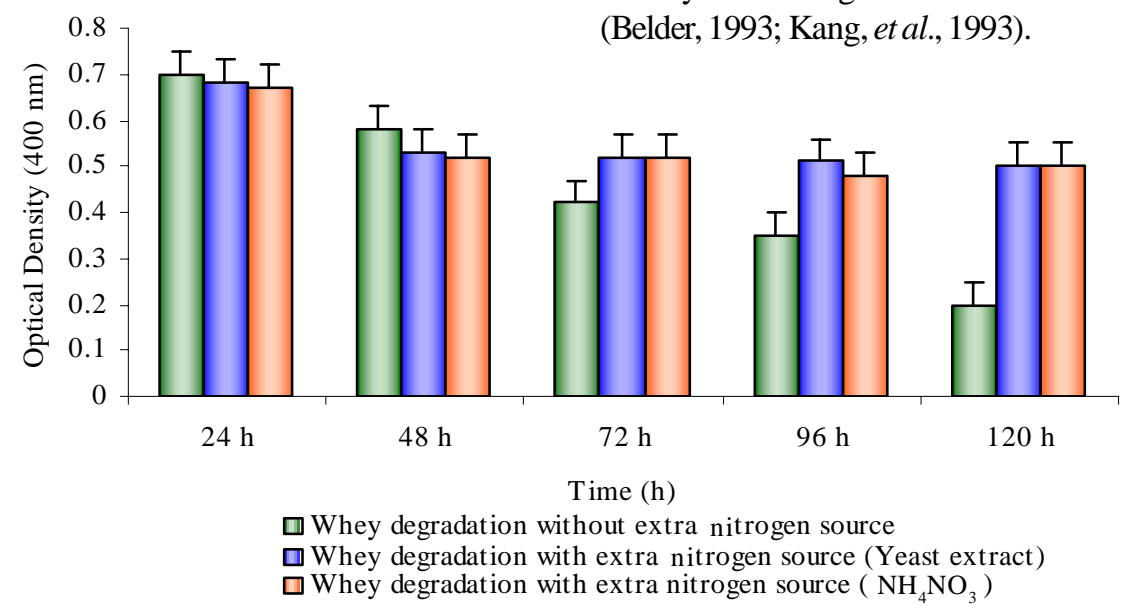

Fig. 1: The effect of different nitrogenous rich compounds (yeast extract and $\mathrm{NH}_{4} \mathrm{NO}_{3}$ ) on whey degradation sources to this level reduced to whey degradation at least 30 \% (Fig 1). Although Azotobacter chroococum 1723 could produce biopolymer at $25^{\circ} \mathrm{C}$ incubation, maximum yields were obtained from fermentation done at $35^{\circ} \mathrm{C}$. Semi-continuous culture results demonstrated that, alginate production as well as whey degradation was decreased (1 mg/mL and 30\%). Transmission electron microscopy assay showed that, bacterial cells have a net-structured polysaccharide capsule around the cells. It formed a compact dense layer of capsular polysaccharide which totally covered the membrane. The color was produced by reaction of alginate samples with and without borate was stable for $2 \mathrm{~h}$.

\section{DISCUSSION AND CONCLUSION}

Whey is a by product of the dairy industry that has presented many disposal problems (Horton, 1993). It is available abundantly in a potential substrate for the production of commercially valuable products (Zadow, 1992). It composed mainly of lactose (4.9\%), protein $(0.9 \%)$, and fat $(0.7 \%)$ that may be used by microorganisms as carbon and nitrogen source for metabolism to support growth and biopolymer production (Table 2). Lactose is the most abundant constituent of whey and it forms at least $78 \%(\mathrm{w} / \mathrm{w})$ of the whey's total solids. This indicates that for an organism to efficiently use whey as substrate, it must be able to metabolize the lactose as its carbon source. Such organisms should produce sufficient lactose hydrolyzing enzymes ( $\beta$-galactosidase) to hydrolyze the lactose to its monomers. The media used for the production of commercial microbial polysaccharides usually contains glucose or sucrose as carbon source (Belder, 1993; Kang, et al., 1993). 
Incorporation of nitrogenous compounds into the medium did not increase whey degradation by Azotobacter chroococcum 1723( $P<0.05)$ This increases the production costs of microbial biopolymer (Hansen, 1993). The growth of the bacteria in whey broths and efficient whey degradation, suggested that the organisms were using other carbon sources present in the whey too. Probably whey proteins are used too because whey total solids are composed of $12 \%(\mathrm{w} / \mathrm{w})$ proteins as shown at Table 2. Different nitrogen concentrations in fermentation broths were achieved by addition of different levels of yeast extract and $\mathrm{NH}_{4} \mathrm{NO}_{3}$ (organic and inorganic nitrogen sources) to a basal medium. Racine, et al. (1991) showed that biopolymer production was enhanced when nitrogen supply was limited and the carbon source was in excess. The results presented in this study Showed that biopolymer production decreased as the nitrogen concentration increased. Embuscado, et al. (1994) observed that inorganic sources gave relatively low to moderate yield of cellulose. The only difference is that in their investigation ammonium nitrogen sources gave better yields, whereas in this study, organic and inorganic sources didn't give better results. This may suggest that in different organic nitrogen sources Azotobacter chroococum 1723 produces biopolymers that differ in rheological quality. Similar observations were made by Kennedy, et al. (1982). Emtiazi, et al. (2004) showed that, addition of vitamin, different nitrogen sources (Ammonium salts, yeast extract and peptone) did not effect exopolymer production in Azotobacter spp. The effect of $\mathrm{pH}$ on biopolymer production has been explained before. Embuscado, et al. (1994) explained that $\mathrm{pH}$ affects both bacterial growth and biopolymer production. When bacterial cells are exposed to $\mathrm{pH}$ beyond their optimum range, maintenance energy is used for $\mathrm{pH}$ control. This reduces the energy available for biopolymer production, thus the bacterial ability to produce the biopolymer is reduced. The media $\mathrm{pH}$ also affects the permeability of the bacterial cell membrane thus affecting the biochemical activities of the cell required for biopolymer production. Emtiazi, et al. (2004) showed that, Azotobacter AC2 produced maximum $(7.5 \mathrm{mg} / \mathrm{mL})$ alginate in media with sucrose as the only carbon source but in this study Azotobacter chroococum 1723 was able to produce exopolysaccharide greater than $5 \mathrm{mg} /$ mL. NMR studies by Moe, et al., (1995) suggested a possible binding site for calcium ions in a single alginate chain. Only alginates having G blocks (alga and Azotobacter alginates) can bind calcium to form rigid gels. Salt concentration of less than $3 \mathrm{mM}$ is sufficient to slow down the kinetics of the dissolution process and hence limits the solubility. Calcium concentration of more than $4.95 \mathrm{ppm}$ in whey broth, so alginate can attach to bacterial cell wall and a few alginate concentrations can be found in supernatant. In semi-continuous culture minimum yields of alginate production and whey degradation were obtained. Dekwer and Hempel (1999) demonstrated that, increasing the dissolved oxygen concentrations in the chemostat condition, the sugar was mainly wasted in respiration. So both growth and alginate formation were clearly affected by dissolved oxygen tensions of the culture medium. They showed that, at the lowest $\mathrm{O}_{2}$ value as well as the highest value, the biomass and alginate formation was minimum yield. Ashraf, et al., (2006) also showed that EPS-producing bacterial isolates was affected by environmental stress. Azotobacter chroococum strains were good $\mathrm{N}_{2}$-fixation strains that investigated in current study. Under conditions of oxygen stress (nitrogenase inactivation) the bacterium produced compact alginate capsules to stabilize the intracellular oxygen concentration at minimal value suitable for nitrogenase activity (Dekwer and Hempel, 1999). These results have clearly shown that whey can be used as a fermentation substrate for the production of biopolymers. Azotobacter spp produced biopolymers (alginate and PHB) of commercial importance. Therefore the production of these biopolymers by whey fermentation can ensure that not only are value added products obtained, but the costly problem of the disposal of whey is also addressed.

\section{ACKNOWLEDGMENTS}

This research was supported by Islamic Azad University, North Tehran Branch, Iran. The authors would like to express their special regards to $\mathrm{Mr}$. Shaykhi for surface tension measurements.

\section{REFERENCES}

Ashraf, M.; Hasnain, S.; Berge, O., (2006). Effect of exoPolysaccharides producing bacterial inoculation on growth of roots of wheat (Triticum aestivum L.) plants grown in a salt-affected soil. Int. J. Environ. Sci. Tech., 3 (1), 43-51.

Belder, A.N., (1993). Dextran, Polysaccharides and their derivatives., third edition. Academic Press, London, 417-499.

Campos, M.E.; Martinez-Salazar, J.M.; Lloret, S.; Moreno, C.; Nunez, Espin, G.; Soberon Chavez, G., (1996). Characterization of the gene coding for GDP - mannose dehydrogenase (algD) from Azotobacter vinelandii. J. Bacterial, 178, 1793-1799. 
Clementi, F., (1997). Alginate production by Azotobacter vinelandii. Crit. Rev. Biotechnol., 17 (4), 327-61.

Crescenzi, V., (1995). Microbiol polysaccharides of applied intrest. Ongoing research activities in Europe. Biotech. Prog., 11, 251-259.

Dekwer, D.; Hempel, D.C., (1999). Microaerophilic production of alginate by Azotobacter vinelandii. Von der Gemeinsamen Naturwissenscha ftlichen, Fakultat der Technischen UN. CaroloWilhelmina zu Braunschweig, Edited by Wael Sabra, aus Alexandria, Agypten, 37-54.

Embuscado, M.E.; Marks, J.S.; BeMiller, J.N., (1994). Bacterial Cellulose. Food Hydrocolloid, 8, 407-418.

Emtiazi, G.; Ethemadifara, Z.; Habibib, M.H., (2004). Production of extra-cellular polymer in Azotobacter and biosorption of metal by exopolymer. African J. Biotech., 3 (6), 330-333.

Flatt, J.H.; Hardin, R.S.A.; Gonzalez, J.M.; Dogger, D.E.; Lightfoot, E.N.; Cameron, D.C., (1992). An anionic galactomannan polysaccharide gum from a newly-isolated lactose-utilising bacterium II. fermentation kinetics and lactose transport. Biotechnol. Progr., 8, 335-339.

Fu. J.F.; Tseng, Y.H., (1990). Construction of lactose utilizing Xanthamonas campestris and production of xanthan gum from whey. Appl. Environ. Microbiol., 56, 919-923.

Grasdalen, H., (1983). High field, 1H-n.m.r. spectroscopy of alginate: sequential structure and linkage conformations. Carbohyd. Res., 118, 255-260.

Hacking, A.J., (1988). Economic and commerical factors influencing the role of biotechnology.In: Kang, R.D and Cheethanm, P.S.J. (Eds.), Food biotechnology. Appl. Sci., 2558.

Hansen, P.M.T., (1993). Food hyrocolloids in the dairy industry. Plenum press, New York., 211-224

Horton, B.S., (1993). Whey processing and utilization. Bull. Int. Dairy Fed., 279, 46-49.

Kang, K.S.; Veeder, G.T.; Cottrell, I.W., (1993). Some novel polysaccharides of recent development. Prog. Ind. Microbiol., 18, 13-17.

Kemp, D.L.; Quickenden, J., (1989). Whey processing for profita worthy alternative. In: Greenshied, R., (Ed.), Resource and application of biotechnology- the new wave. Macmillian Ltd. Basingstoke., 2323-2331.

Kennedy, J. F.; Jones, P.; Barker, S. A., (1982). Factors affecting microbial polysaccharide production during the fermentation of Xanthamonas campestris cultures. Enzyme Microbiol. Technol., 4, 39-43.
Kirk, R. S.; and Sawyer, R., (1991). Pearsons composition and analysis of foods, $9^{\text {th }}$ edition. Longman Scientific Technical, Harlow, England, 16-21.

Konicek, J.; Lasik, J.; Safar, H., (1993). Production of exopolysaccharide by a new mutant strain of Achromobacter delicatulus using whey fermentation. Folia Microbio., 38, 68-70.

Low, D. J. A.; Ahlgren, D.; Horne, D. J.; McMahon, C. J.; Oberg; Broadbent, J.R., (1998). Role of Streptococcus thermophilus MR-1C capsular extracellular polysaccharide in cheese moisture retention. Appl. Environ. Microbiol., 64, 2147-2151.

Moe, S.T.; Draget, K. I.; Skjak Braek, G.; Smidsrod, O., (1995). Alginates in food polysaccharide and application. Edited by M. Dekker. New York., 9, 245-286.

Neidleman, S.L., (1991). Microbioal production of biochemical. The genetic engineer and biotchnologist. Biopaper J., 20-22.

Otterlei, M.; Ostgaard, K.; Skjak-Braek, G.; Smidsrod, G., (1991). Induction of cytokine production from human monocytes stimulated with alginate. J. Immonother., 10, 286-291.

Racine, M.; Dumont, J.; Champagne, C.P.; Morin, A., (1991). Production and characterization of the polysaccharide from Propionibacterium acidipropionici on whey based media. J. Appl. Bacteriol, 71, 233-238.

Sabra, A.; Zeng, P.; Lonsdorf, H.; Deckwer, W.D., (2000). Effect of oxygen on formation and structure of Axotobacter vinelandii alginate and its role in protecting nitregenase. Appl. Environ. Microbiol., 66, 4037-4044.

Schwartz, R.D.; Bodie, E.A., (1985). Production of high viscousity whey broths by lactose utilizing Xanthomonas campestris strain. Appl. Environ. Microbial., 50, 1483-1485.

Vendrusculo, T.V.; Pereira, J.L.; Scamparini, A.R.P., (1994). Gellan gum production and properties. In: Nishinari. K. and Doi, E. (Eds.), Food hydrocolloids: structure, properties and function. Plenum Press, New York., 91-95.

Willis, D.R.J.; Holmatadt, T.G.; Kinscher, F., (2001). Genetic evidence that loss of virulence associated with gac $\mathrm{S}$ or $\mathrm{Gac}$ a mutation in Pseudomonas syringae does not result from effect on alginate production. Appl. Environ. Microbiol., 67, 1400-1409.

Zadow, J.G., (1986). Utilisation of milk components: Whey.In: Robinson, R.K. (Ed), Modern dairy technology, Advances in milk processing. Appl. Sci., 1, 273-317.

Zadow, J.G., (1987). Whey production and utilization in Oceania. Bull. Int. Dairy Fed., 212, 12-16.

Zadow, J.G., (1992). Review and report on whey utilization. A report for the dairy research and development. Bull. Int. Dairy Fed., 314, 21-23.

\section{AUTHOR (S) BIOSKETCHES}

Khanafari, A., Ph.D. is a assistant professor in the Department of Microbiology, and head of experimental sciences in Islamic Azad University, North Tehran Branch, Iran. Email: khanafari_a@yahoo.com

Akhavan Sepahei, A., Ph.D. is a assistant Professor and lecturer in the Department of Microbiology, in Islamic Azad University, North Tehran Branch, Iran. Email: abakhavan@yahoo.com

This article should be referenced as follows:

Khanafari, A.; Akhavan Sepahei, A., (2007). Alginate biopolymer production by Azotobacter chroococcum from whey degradation. Int. J. Environ. Sci. Tech., 4 (4), 427-432. 